\title{
Tacit Knowledge, Tacit Ignorance, and the Future of Academic Librarianship
}

\section{Bill Crowley}

\begin{abstract}
This theoretical essay uses tacit knowledge, the often-undocumented wisdom of expert practitioners and practitioner communities, to explore future prospects for the academic librarian. Traditional and emerging valuations of the academic librarian held by higher education stakeholders are identified. The practical implications of these views for university funding and other support are explored using the philosophical stance of cultural pragmatism and by applying the sociological perspective of the "stranger," tacit knowledge gained by the author as a researcher and a faculty member in an LIS program and as chair of a university Committee on the Library, and insights from a spectrum of publications. In the process, the March of Dimes, an organization that successfully repositioned itself after accomplishing its primary purpose, is examined as a possible model for enhancing the academic librarian's perceived value.
\end{abstract}

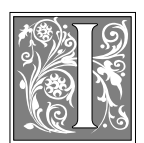

$\mathrm{n}$ their book, The Social Life of Information, John Seely Brown and Paul Duguid described a colleague at the University of California-Berkeley who "sang the praises of the digital world" after the university provided direct access to a wealth of electronic information. ${ }^{1}$ In recounting this anecdote, Brown and Duguid noted that their colleague was clearly overlooking the extended network of institutions and individuals needed to produce the digital library that served him so well. According to Brown and Duguid, the unacknowledged participants in this information development, organization, and delivery chain range from the university and its library to publishers, editors, referees, authors, computer specialists, and librarians, including catalogers and collection managers. Although the contributions of all involved make such information delivery possible, to quote Brown and Duguid, "when information takes center stage and lights dim on the periphery, it's easy to forget these necessary intermediaries. But while these may be invisible, they are not inconsequential."

At first reading, academic librarians may see much to praise in Brown and Duguid's reminder of the undeniable place of librarians-and others-in ensuring broader information availability. Yet, such a response might well represent a fundamental misinterpretation of the mind-set of these researchers. When viewed from the perspective of faculty tacit knowledge, here briefly defined as the private knowl-

Bill Crowley is Associate Professor in the Graduate School of Library and Information Science at Dominican University; e-mail: crowbill@email.dom.edu. This article grew out of a presentation by the author to a March 15-16, 2001, conference on knowledge management for academic librarians sponsored by Dominican University's Center for Knowledge Management. 
edge or "the often-undocumented wisdom possessed by expert practitioners," Brown and Duguid's praise of those who are not researchers, who do not create new knowledge, is worse than merely lukewarm. ${ }^{2}$ As a professional commendation, it almost epitomizes the proverbial damning with faint praise.

A close reading of Brown and Duguid's book will reveal to those who have been sensitized to the discourse prevalent in major universities that the authors view the researcher, both the corporate and the faculty researcher, as the intellectual gold standard, the template against which everything else in the university and larger world of inquiry must be measured. In effect, by terming librarians, publishers, and even reviewers for refereed journals, who, ironically, may be fellow researchers, as peripheral, invisible, and not inconsequential, Brown and Duguid provide evidence that a particularly strong set of values-values prizing originality and creativity-is in play. ${ }^{3}$ This set of values is comparable to those advanced in years past by Jacques Barzun, former provost of Columbia University. In his classic work, The American University: How It Runs, Where It Is Going, Barzun distinguishes the work of scholars from the less praiseworthy efforts of "machine salesmen" (computer professionals) and "intellectual middlemen" (librarians and journalists). ${ }^{4}$ The latter, he stressed, overlook the matchless value of the scholarly mind and thereby assume, quite erroneously, that "knowledge is the assembling of items found here and found there, the act of finding being research." ${ }^{5}$

In American higher education, the peripheral, the invisible, and the not-inconsequential elements identified by Brown and Duguid also should be viewed as "expendable." These are the components of academic life that can be sacrificed, for example, to protect what the University of Chicago, Northwestern University, the University of Notre Dame, or smaller institutions deem to be more central, visible, and consequential to and in their missions. For an academic librar- ian, the rise of what are increasingly seen as more or less acceptable electronic alternatives to her or his professional services should be a very strong stimulus to identifying where librarians really rank in their own educational contexts. Here, it must be stressed that librarians make a crucial mistake if they believe that boards of trustees, presidents, and research/ teaching faculty only support alternatives to university programs that are better than, or at least as good as, the originals. In reality, substitute services do not have to offer better or comparable quality. Replacement services only have to be "good enough to get the job done," according to the operative definitions of those who make significant college and university decisions on resource allocation.

University presidents do not often admit, at least in public, that they will settle for second or even third best when circumstances require. However, one such admission actually does appear in what generally is considered the most influential book ever written on higher education, John Henry Newman's Idea of a University. In this work, Newman, founding head of the Catholic University of Ireland and later cardinal of the Roman Catholic Church, admitted that "in a particular instance, it might easily happen, that what is only second best is best practically, because what is actually best is out of the question." ${ }^{\prime 6}$

In the century and a half since his book was first published, Newman's words have undoubtedly been a balm to numerous university heads forced to compromise on their principles during periods of perceived austerity. Those who believe that higher education's leaders will only replace the good with the better, rather than settle for the simply good enough, might want to take Newman's reminder to heart.

The threat of being seen as peripheral, invisible, and not inconsequential should encourage academic librarians to design and sustain service programs that appeal to those who have the power to alter or sustain value definitions in their particular academic contexts. Moreover, it should 
be a strong incentive to initiate or continue both short- and long-range efforts to ensure that the librarian, in any academic environment, is seen as central, visible, and consequential.

Fundamental to this essay is the argument that academic librarians will have a strong voice in helping to define their own futures only when they have a better understanding of the tacit knowledge, the professional wisdom, of boards of trustees, administrators, faculty, and forprofit corporations-the more significant players on university campuses and in higher education's emerging cyber communities. It is yet another premise that the composition of such tacit knowledge, and the resulting implications for librarian action, will vary on the level of the individual academic institution.

\section{Outline of This Essay}

In analyzing how understanding the tacit knowledge of the significant players on the academic scene can enhance the actual effectiveness of the academic librarian, as well as the perception of such effectiveness by the larger academic community, this essay addresses issues such as

- cultural pragmatism as a research philosophy;

- tacit knowledge definitions;

- roles of the "stranger";

- changing academic environments;

- Do We Need Academic Libraries? (ACRL position paper as academic culde-sac?);

- goal achieved (lessons from the March of Dimes experience);

- short-term survival (librarian as fellow teacher?);

- long-term survival (librarian as research colleague?);

- closing questions and context-specific answers.

\section{Cultural Pragmatism as a Research Philosophy}

Cultural pragmatism is a research philosophy grounded in the pragmatism advanced in the early twentieth century by William James and John Dewey. However, unlike various "classic" versions of its intellectual parent, cultural pragmatism is open to newer understandings from such philosophical schools as feminism and critical theory. Admittedly, pragmatism's emphasis on the directive power of analyzed experience, and the fact that such experience is open to interpretation on the individual level, can and does lead to quite a number of definitions. Still, even with every scholar advancing her or his own understandings of what pragmatism really is, contemporary cultural pragmatists are likely to tolerate, if not embrace, most, if not all, of the following assertions:

- Knowledge and meaning are determined by experience.

- Research is instigated by a problem.

- Ideas are instruments for defining and solving problems.

- Philosophy and theory development are human endeavors, subject to human limitations.

- Propositions are meaningless unless their being true or false will make a difference in our lives.

- Meanings always require human context; there are no eternal essences or ideal objects.

- Theories are, at best, provisionally true and are always subject to further testing in a variety of contexts.

- What counts is not where ideas come from, but what we can do with them.

- Facts always involve an element of value, and values cannot be conceived in isolation from the world of concrete events.

- Any attempt to improve the world must begin by finding out how the world actually works.

- Humans have the best opportunity to develop their capabilities in a democracy.

- Scientific and other knowledge progress best in a democratic context that encourages freedom of inquiry. ${ }^{7}$

In the spirit of cultural pragmatism, it must be stressed that any assertions made 
by the author of this essay regarding the prospects for using tacit knowledge in the academic library ought to be tested by the reader for relevance in her or his individual context. ${ }^{8}$ No cultural pragmatist worthy of the name will attempt to sell a one-size-fits-all approach to understanding tacit knowledge in university or college environments. At best, scholars can provide practitioners with reliable road signs, distance markers, and directional indicators as to what knowledge might be useful within a given local, national, or even transnational context.

\section{Tacit Knowledge Definitions}

"We can know more than we can tell," an adage offered by Michael Polanyi, scientist, philosopher, and author of the influential Tacit Dimension, may be the most quoted observation in the tacit knowledge research enterprise. ${ }^{9}$ Recent studies in the business, sociological, psychological, military, and other research literatures have expanded this concise definition to include assertions that tacit knowledge is:

- personal in origin;

- valuable to the possessor;

- job specific;

- related to context;

- difficult to fully articulate;

- both known in part and unknown in part to the possessor;

- transmitted, where transmission is possible, through interpersonal contact;

- operative on an organizational level;

- applied, in part, through "if-then" rules (if certain conditions exist, then apply the following);

- capable of becoming explicit knowledge and vice versa;

- intertwined with explicit knowledge along unstable knowledge borders;

- poorly reflected in contemporary knowledge literature. ${ }^{10}$

It also is possible to view tacit knowledge as Philip Coyle's technical intuition, the sort of knowledge " that gets built up over decades of personal success and failure." ${ }^{\prime 11}$ The lack of precision in defining tacit knowledge may well reflect the na- ture of the concept. As with the term furniture, which can be defined at the level of the individual, tacit knowledge is a natural concept-people can generally agree on such core elements as chairs or tables, yet differ over whether personal computer peripherals placed next to a desk are pieces of equipment, items of furniture, or both. ${ }^{12}$

\section{Exceptional circumstances aside, humans tend to want definitions of the world that confirm current perceptions of reality.}

Of late, researchers in the area of tacit knowledge have addressed the reality that communities of practice often share tacit understandings or unconscious work norms that serve to "guide much of the interactions among members. ${ }^{\prime 13}$ It is a contention of this essay (see below) that a separate academic community of practice based on librarian-specific tacit knowledge is becoming increasingly difficult to sustain in light of restrictions in resources and increased competition in both external and internal university environments. ${ }^{14}$ Bluntly stated, the "zerosum game" seen by Felix T. Chu as operating in the area of academic library collection development will increasingly describe future relations among academic librarians, research/teaching faculty, administrators, and boards of trustees. ${ }^{15}$

At a minimum, the dollars allocated to pay a new instructor in order to reduce the teaching load assigned a world-class scholar lured from a major research university cannot be spent simultaneously to employ (1) a faculty-outreach librarian, (2) a grant writer, (3) a student recruiter, or (4) a secretary to the board of trustees.

\section{Roles of the "Stranger"}

Discussion of the value of the "stranger" can begin with a consideration of what a stranger is and what he or she may do for academic libraries and librarians seeking to justify their continued existence. For Simonetta Tabboni, the stranger is an outsider who interacts with a group, and 
may even share its geographical area, but "feels no loyalty to the cultural traditions of the community, nor to the solidarity networks which give cohesion to the group." ${ }^{16}$ Most closely associated with the sociologist Georg Simmel, the concept of the stranger (as used in this essay) refers to someone who is knowledgeable about academic libraries but is not employed as an academic librarian. ${ }^{17}$

The author of this essay fits this definition of stranger in a number of ways. $\mathrm{He}$ is a faculty member in a school of library and information studies (LIS) and served three years as chair of his university's Committee on the Library. In addition, he completed a dissertation on the research university library while earning a Ph.D. in higher education and has published on the status of the academic librarian in journals such as College $\mathcal{E} R e^{-}$ search Libraries and the Canadian Journal of Information and Library Science. ${ }^{18}$ More recently, he was appointed to Dominican University's Rebecca Crown Library Building Renovation Blue Ribbon Committee and asked to play a particularly intense role in the library renovation planning. ${ }^{19}$ Not being an academic librarian, but possessing a knowledge of the workings of academic librarianship, he is a stranger with an outsider's perspective on the current status and future prospects of the academic librarian.

The more valuable contributions of a stranger to a discussion of the future of academic libraries may be easily summarized. When the stranger is not an academic librarian, he or she has a different view of reality. As William G. Tierney pointed out, reality is not something "objective" or "external." Rather, "reality is defined through a process of social interchange in which perceptions are affirmed, modified, or replaced [essay author's emphasis] according to their apparent congruence with the perceptions of others." ${ }^{20}$

Tierney's last point that perceptions can be affirmed, modified, or replaced in a given context is worth an extended consideration. For the most part, academic librarians operate with the same "it's our world and we want to define our way" approach preferred by any other professional group. Exceptional circumstances aside, humans tend to want definitions of the world that confirm current perceptions of reality. Such a reality may not be preferred, but at least it is known. In normal times, even the future is perceived as representing some variant of the present, but suitably modified to accommodate technical changes.

However, every so often a changing context so threatens a profession that the profession is forced to revisit issues thought settled long ago. At such times, the conventional wisdom tied to the accepted values of a given group often fails to provide answers to critical questions. When the very worth of the academic librarian is subject to question, can the often disagreeable-and even occasionally repugnant-advice from a stranger acquire more than a passing interest?

For academic librarians, the early twenty-first century has become a time of unexpected questions and inadequate answers. Oswald M. T. Ratteray, assistant director for constituent services and special programs of the Middle States Commission, recently raised one such question. In August 1999, he wrote to the library directors at the commission's member institutions to ask, very simply, "Does a degree-granting institution of higher education need a physical library (and librarians) for accreditation?"21

In reviewing the background leading to this question, Larry Hardesty stressed that this formal revisiting of the value of the academic library and the academic librarian developed out of the Middle States Commission's efforts to handle the accreditation of both transregional and virtual institutions. The manner in which transregional and virtual institutions are accredited is important to all higher education institutions because the new standards applicable to them also will pertain to conventional university campuses. The point is worth repeating: accrediting bodies must apply comparable standards in recognizing program quality. Whatever 
leeway is granted to new types of universities also must be granted to their brickand-mortar predecessors. And the very definitions of transregional and virtual universities suggest that the old accreditation rules no longer need apply.

Ratteray wrote that:

\begin{abstract}
A transregional institution is one that is chartered and has its principal operation in one of the six accrediting regions in the United States and has a branch or other instructional location in the other regions. A virtual institution maintains a limited physical plant at its headquarters and transmits its courses and provides learning resources to students at a distance, usually electronically via the Internet, by mail, or some combination of electronic and print media. ${ }^{22}$
\end{abstract}

Subsequent to his letter, another source of regional accreditation, the Commission on Colleges of the Southern Association of Colleges and Schools, proposed new accrediting "principles" and "requirements" that eliminate language calling for "libraries, librarians, or the need for a graduate education to work in libraries."23 These developments have far-reaching implications for the future of the academic library. In consequence, it is useful to review why librarians now face the possibility - in some, but not all, higher education contexts —of becoming merely discretionary employees, of devolving from a critical part to merely an optional component of academic life.

From the perspective of administrative and faculty tacit knowledge, the perception that academic librarians now may be redundant is not a judgment of professional failure. On the contrary, this nascent, yet growing, view spreading among these important sectors of the university world holds that academic librarians have actually achieved a large part of their historic mission. The evidence, provided through office and home terminals and increasingly effective access to
Web sites, clearly demonstrates that academic librarians are providing unmediated access to a sufficient quality and quantity of the information needed by teachers and students. In addition, academic librarians are similarly responding (again, in electronic formats) to the more complicated demands of scientific researchers and humanities scholars. In short, academic librarians seem to be working themselves out of a job precisely at a time when universities and colleges are looking to restrain costs as part of strategies to counter threats from traditional and emerging competitors, many of whom are delivering courses through electronic formats.

\section{Changing Academic Environments}

In The McDonaldization Thesis, sociologist George Ritzer described an evolving world where "the university is a means of educational consumption" and parents and students are approaching higher education with a new consumer mentality, a perspective prizing low cost, high quality, and convenience..$^{24}$ In reality, an emphasis on cost, quality, and convenience is nothing new. Historians of higher education have seen such factors operating since at least the middle ages. ${ }^{25}$ Nevertheless, it is a long-standing social science truism that if enough people define something as real, it can often become a selffulfilling prophecy with genuine consequences. ${ }^{26}$ In the early twenty-first century, academic decision makers operating on the low-cost/high-quality / greater convenience trinity are running into a number of inherent problems: (1) convenience may require the sacrifice of quality; (2) maintaining program standards often demands a considerable commitment of resources; and (3) rigorous efforts at quality control of classroom teaching intensify long-standing faculty concerns regarding academic freedom. ${ }^{27}$

One model of how educational costs can be contained is the former Harcourt Higher Education. Within this for-profit educational pattern, (1) library support is primarily electronic in nature; (2) contrac- 
tual access by students to a traditional brick-and-mortar library and a local library cooperative is provided only because of the demand of a state accrediting agency; (3) students are instructed on how to use other libraries when the resources of the online library may be insufficient and access to the contracting library is, apparently, inconvenient; and (4) instructors, primarily part-time and using "canned" syllabi produced by fulltime educators, are "encouraged to add or replace $15 \%$ of the resources provided with materials of his or her own choosing, including virtual field trips or other articles and Internet sites." 28

Variants of the Harcourt approach may well set a standard, albeit a lower one by traditional academic norms, for academic institutions not in the reputational top tier and that must restrict costs more than the so-called educational brand names. However, some argue that even the perceived leaders of the university world will be transformed through the action of the educational marketplace. ${ }^{29}$ If a commitment to low cost means that parents and students as consumers will not be charged the necessary dollars to support, for example, first-rate library service and fulltime teaching faculty, the university as seller of degrees and other credentials will keep prices low by pressuring students to do more of the work on their own. According to Ritzer, the result will be a situation where:

Like their brethren who transact business at the local ATMs (as well as at fast-food restaurants and in interaction with cybermalls), students will be forced to do more of the labor within the new means of education; they will educate themselves more and more on their own in interaction with images emanating from their computer and television screens. Like much else, this development will be driven by cost considerations. Students do this work for free and as a result universities are able to do without the many highly paid employees previously needed to help and instruct them. ${ }^{30}$

The implications of this administrative mind-set for both academic librarians and classroom faculty are particularly disturbing. If, for example, students can be provided with more or less adequate information resources through university Web pages, and instruction in the use of such resources can be transferred from librarians to faculty teaching in real or electronic classrooms, there looms the possibility of substantial cost-savings. The parallel with the rise of OCLC, the spread of copy cataloging, and the subsequent elimination of the jobs of many professional catalogers should be evident to most academic librarians.

The proposed scenario seems rather simple: If librarians and libraries are no longer required for accreditation purposes, if vendors stand ready to provide minimally adequate electronic information resources, if backup assistance is available from librarians or other human resources employed by for-profit corporations, and if the instruction of students in the use of information resources can be transferred to full- and part-time faculty, then why do we have any, or so many, academic librarians?

Fundamental to an administrative mind-set that seriously considers the possibility of eliminating academic librarians or, at a minimum, reducing their number to the level required to maintain vendor contracts and handle the occasional and very specialized requests of faculty researchers is a critical assumption. This assumption, whether viewed as resulting from managerial tacit knowledge or administrative tacit ignorance, can be summarized briefly. It is the belief that decades of computerizing information, under the leadership of academic librarians or produced to meet their needs, are making all but the most esoteric information available in electronic formats.

For many academic librarians, particularly those employed in research universities, this assumption is so absurd that 
the expected reaction can be largely emotional. Those who seek to interpret, or even bring up, perceptions of librarian redundancy-the proverbial messengersare likely to meet demands from librarians for absolute proof of their assertions, ideally in the form of extensive national surveys and in-depth interviews with higher education presidents.

Of late, a university president who walks into a contemporary academic library may notice a distinct lack of people.

The counter to such demands for such specifics, presumably involving putting university presidents under oath to encourage truthful testimony, is to emphasize that the university seldom works at the level of such candor. Clark Kerr, president emeritus and former chancellor at the University of California system, has long been known for his willingness to "surface" presidential tacit knowledge, the professional wisdom that serves university leaders. Repeatedly, Kerr has asserted that straightforward presentations of presidential views on major issues are counterproductive for career longevity.

As stressed by Kerr:

Presidential survival depends ... on not calling undue attention to longer-run difficult prospects, on making adjustments year by year, on choosing adjustments that lead to the least powerful immediate protests (as by cutting plant maintenance and the purchase of books), on encouraging early retirements on favorable terms, on postponing new appointments, and on not making adjustments that can be pushed up the line to trustees-or out to external authorities, or down to the provosts and deans, or that can be saved for the attention of successors. Survival depends heavily on not disturbing any current faculty members. Some presidents are dedicated more to duty and some more to sur- vival-thus far in quite unequal proportions, in part because the latter at least survive. ${ }^{31}$

Because of such higher education realities, it is doubtful that any researcher could secure "reliable" documents or dependable oral testimony stipulating the "real" reasons why university $X$ or college $\mathrm{Y}$ reduced the number of librarian personnel lines or even outsourced its library. However, cultural pragmatists only claim to have contingent answers that are subject to confirmation or rejection in individual contexts on the basis of local experience. John Henry Newman is long gone. Contemporary presidential survival often requires the obscuring of unpleasant truths under platitudes relating to enhanced effectiveness. Under such circumstances, the present writer has no choice but to utilize pragmatism's "recognized place for hypotheses which at a given time outrun the scope of already determined 'facts,' and which, indeed, may not be capable of verification at the time or of direct factual verification at any time." 32

Theoretically speaking, the hypotheses advanced in this essay are delivered strictly caveat emptor. There are no warranties that the information provided herein is valid in a given academic context. However, the assertions are drawn from both the author's formal and continuing studies on the various higher education environments and, equally important, his faculty tacit knowledge. In this same spirit, the author would be most appreciative of receiving accounts from academic librarians that would correct, verify, or even disprove the assertions advanced in the current work.

Real-world answers to the question, Why would an administrator even consider operating a university without an academic library? are at best suggestive. First, the idea is now in the air. Why else is ACRL publishing papers against it? If subtracting the physical library from higher education were not an idea that has significant momentum, why would 
regional accrediting associations change their criteria to accommodate the deletion? Second, for-profit and other higher education competitors that emphasize the convenient delivery of courses, use parttime faculty, and forgo expensive investments in libraries, sports stadiums, and other so-called "peripherals" can charge less for their degrees than more traditional counterparts. To protect her or his educational base, a university president must give serious thought to ways of implementing cost reductions without alienating significant academic players. And librarians without faculty allies are simply not significant players on a university campus.

Of late, a university president who walks into a contemporary academic library may notice a distinct lack of people. This is a recent, dramatic, and even revolutionary change in campus life. As Evan Ira Farber observed, academic librarians used to be able to count on a critical mass of students seated at library tables, "reading books on reserve, or using the library as simply a quiet, comfortable place to read their own textbooks." ${ }^{33}$ Now, students and faculty are noticeable by their absence from library buildings, even if they are dramatically increasing their use of the library's electronic resources.

From the perspective of presidential tacit knowledge, librarian claims, however well documented, that students and faculty may be using library electronic resources intensely through connections made in dorm rooms, offices, and via the Web can be almost self-defeating. Proof of the success of out-of-library information transactions may even spur presidential doubts regarding the cost-effectiveness of physical library facilities.

\section{Self-inflicted Wounds?}

What academic librarians seemingly have achieved through making a significant amount of information more conveniently available to faculty and students is a textbook example of a classic sociological theory advanced decades ago by Robert K. Merton. As a direct result of their own actions, they are experiencing the "unanticipated consequences of purposive social action." ${ }^{34}$ Granted, the Library of Congress, corporate information specialists, numerous commercial firms, and other database developers must share in the credit. Nonetheless, it was the intensive efforts of academic librarians to make adequate information conveniently available that, in Merton's formulation, now contribute to releasing "processes which so react as to change the very scale of values which precipitated them." 35

\section{Academic librarianship took a leadership role in moving the American academy from a reliance on paper and ink to a growing dependency on electronic informa- tion resources.}

This transformation in the valuation of the librarian in higher education brought about by the electronic environment is nothing short of incredible. Whether viewed as faculty peers or professional support staff, librarians used to be considered an inescapable part of academic life. The academic librarian's role might have been debated, but it was always assumed.

Now, to vary and extend an earlier question: When we have information available from desktops, who needs libraries? Who needs librarians?

From the viewpoint of the informed stranger, it is particularly unfortunate that the very organization expected to provide leadership in answering these question in terms acceptable to the tacit knowledge, the professional wisdom, of university administrators and faculty has elected to take another course. Rather than helping to chart a positive future for the academic librarian, by issuing Hardesty's Do We Need Academic Libraries? as an official position paper, the ACRL may have embraced a self-defeating version of what former British prime minister Margaret Thatcher disparaged as "yesterday's future." 36 Viewed from the standpoint of this researcher's tacit 
knowledge, as well as explicit knowledge drawn from extended studies of the higher education literature on the preferences and prejudices of other academicians, it can be safely argued that the ACRL has accomplished an incredibly difficult task. Through publication of Do We Need Academic Libraries? it has managed to misunderstand and insult teaching faculty while simultaneously demanding that professors help save the academic librarian from the potentially career-destructive, unanticipated consequences of making a greater amount of information more readily available.

\section{Do We Need Academic Libraries? ACRL Position Paper as Academic Cul-de-Sac?}

The literature of academic librarianship occasionally produces publications that are particularly successful in capturing the values and interests of the teaching and research faculty. In one such work, Wade R. Kotter found that accounts of librarian-faculty relations tend to be anecdotal and describe situations that "are most often strained, unfriendly, and even acrimonious." Negative anecdotes by librarians, he noted, seem to be "always highly dramatic and often intensely emotional," whereas positive anecdotes by librarians "are often low-key and sometimes even apologetic." ${ }^{\prime 3}$

Although Kotter's analysis of academic librarian stories about faculty is informative, his discussion of "anecdotes related by classroom faculty" has particular relevance for the issues addressed through this essay. He asserted that:

By comparison anecdotes related by classroom faculty tend to be more positive about relations with librarians. This should come as no great surprise, because most of these accounts stem from invited talks given by classroom faculty before large groups of academic librarians. Like most people, including librarians, classroom faculty are much less likely to express their displeasure in public than in private, especially when invited to speak to a large group representing the object of that displeasure. And those classroom faculty with highly negative attitudes towards the library are less likely to be invited to speak and more likely to turn down such an invitation if one were extended. Thus, the generally positive tone of these presentations is not sufficient evidence that all is well. ${ }^{38}$

Unfortunately, all is not well in the relationships between the teaching/research faculty and the academic librarian. Worse, the publication of Do We Need Academic Libraries? is not going to make them any better. In only a few short pages, the work manages to ignore the academic librarian's own responsibility for problems arising from an overvaluation of electronic information, even as it displays a remarkable ignorance of the professional cultures of the teaching/research faculty.

The notion that academic librarians can avoid their responsibility for helping to bring about the uncertain world of electronic information deserves additional attention. Academic librarianship took a leadership role in moving the American academy from a reliance on paper and ink to a growing dependency on electronic information resources. As a profession, it advanced such a radical transformation without making adequate provision for the foreseeable impact on existing, building-based programs when a significant part of library resources could be accessed without entering a library facility.

Even more problematic, through a continuing failure to embrace faculty norms, librarians-as exemplified in Do We Need Academic Libraries?-have shown they have not fully understood that, for example, the teaching faculty can and will make electronic resources work for the benefit of their students in both brick-and-motor and electronic classrooms. 


\section{Misreading the Values of the Teaching/Research Faculty}

From the perspective of teaching/faculty values, it is both absurd and counterproductive for the ACRL to promulgate the view advanced in Do We Need Academic Libraries? that "If neither the on-campus nor the distance education student goes beyond the textbook and any other prepackaged materials, both are being cheated out of the opportunities to receive a college education." ${ }^{39}$

First, neither teaching faculty nor academic administrators normally accord academic librarians the right to comment on the success of given courses or fulldegree programs. Teaching faculty already view themselves as assessed enough by students and administrators who may have no understanding of what instruction actually demands. ${ }^{40}$ Any attempts by librarians to evaluate what teaching faculty do are likely to be seen as an unwarranted intrusion into the educational process by the unqualified. Although administrators in community colleges have more control, the faculty of research universities jealously guard both the curriculum and admissions policies, particularly against presidents and deans who are perceived to be willing to water down both for the sake of additional revenue or nonacademic goals. Comments by academic librarians, unless such librarians regularly teach courses in the department, are deemed inappropriate. Even librarians with ongoing responsibilities for teaching credit-bearing, revenue-raising courses are likely to face the occasional reminder that they simply do not understand the curriculum as well as the fulltime faculty do.

At a minimum, academic librarians flunk the "atrocity story" test. Atrocity stories, narratives "by which a straightforward complaint or slight is transformed into a moral tale inviting all rightthinking persons (the audience) to testify to the worth of the teller as against the failings of the other characters in the story," help define professional groups. ${ }^{41}$ Librarians, as Kotter noted, tell atrocity stories about the teaching/research faculty. ${ }^{42}$ On the other hand, the teaching/ research faculty tell atrocity stories to each other about college deans, university presidents, and even academic librarians-sometimes perceived as having spent their days sitting virtually undisturbed even at reference desks-who leave work at night with no papers to grade or lessons to prepare.

Second, if academic librarians truly understood the tacit knowledge of the teaching faculty, they would know that professors have a tradition of making things work for their classes under oftendifficult circumstances. Exposing students to the widest possible spectrum of library resources is always positive. However, given job demands, family responsibilities, and distances to campuses, students, particularly "adult" students, may not have much time to spend in a library. Under such circumstances, a good teacher can be expected to take what the ACRL condemns as "the textbook and any other prepackaged material" and, through her or his teaching skills, produce a first-rate educational experience. To paraphrase John Henry Newman, it may be second best, but it can often be made practical best.

Third, in the position paper Do We Need Academic Libraries? ACRL appears to apply to university teaching the same "intellectual middleman" misunderstandings that Barzun condemned in the area of faculty research. ${ }^{43}$ To echo Barzun, in teaching as in research, it is the "action of mind" that is critical. At some point, access to more and more information for teaching purposes, as opposed to research, threatens to become mere datastockpiling. Given an essential minimum in both the quantity and quality of information, delivered through electronic means in formats baptized as acceptable through decades of commendable work by academic librarians, the real issue for faculty as teachers does not lie in overwhelming students with data. Rather, it consists of working with students to transform information into knowledge 
and, in the process, to occasionally approach real wisdom.

Fourth, teaching faculty are entering a time when academic administrators are demanding increases in the number of courses taught and even making unpleasant noises about outsourcing college teaching itself. ${ }^{44}$ When faced with such threats, the teaching faculty are unlikely to be sympathetic to the travails of academic librarians who helped create the environment for electronically delivered education and now complain that the system they brought into being is threatening their preferred way of doing business. If pushed, teaching faculty will remember that libraries and librarians exist to support the curriculum. They may be quite willing to outsource library services in an effort to preserve core teaching functions. ${ }^{45}$ When costs become an increasingly important item, is it likely that teaching faculty will agree, for example, to add another course per semester (without additional compensation) if that is the price for maintaining the more or less traditional scenario for academic library service defended in Do We Need Academic Libraries?

Teaching/research faculty are not unsympathetic to the concerns of academic librarians. Indeed, some faculty bodies may even endorse the message detailed in Do We Need Academic Libraries? However, any such endorsements should be evaluated in light of the two types of theories of action analyzed by Chris Argyris. ${ }^{46}$ The first type of theory is the espoused theory, which is "usually expressed in the form of stated beliefs and values." Espoused theory usually can be contrasted with the second type of theory of actionthe theory that people, including faculty, actually use. The theory in use cannot be determined from endorsements or position papers, it can only be inferred, as Argyris noted, from observing "actions" and "actual behavior." 47

Productive discussion of the future must begin with the possibility that the tacit knowledge of university faculty and administrators, using the evidence sup- plied through university Web sites and online access, now sees academic librarianship as having achieved, in a very visible fashion, its long-term goal of supporting teaching, learning, and scholarship through the provision of reliable information resources. From homes, offices, and even library terminals, professors, administrators, and students throughout the United States and other developed nations are increasingly downloading data, information, and even knowledge. In strategic terms, at least in the developed world, the long-sought breakthrough has occurred. Thanks in large measure to decades of work by academic librarians, higher education is becoming an enterprise supported largely through electronic information.

At the level of tactics, faculty and administrators will recognize that some cleaning-up work still must be done. Critical information from collections accumulated in the past must be digitized, and the numerous resources that may never be placed online must be preserved. But this sort of work may be considered a matter of largely filling in the blanks. The relevant questions now seem to be:

- Should a book or journal be acquired in hard-copy format, electronic format, or both?

- Should access to the work be leased from a for-profit provider?

Of course, the realities of effective library service are much more complex than this simplified scheme. However, it is a little publicized aspect of tacit knowledge that it does not have to be "objectively" correct; it simply has to work. If, for example, a university president cuts back on library support to help stabilize tuition and the teaching faculty somehow make electronic resources "work" for students largely in the absence of librarians, then the initial action of laying off a few academic library staff has, in hindsight, "worked."

This scenario, which was not possible prior to the rise of electronic information and coming changes in accreditation standards, has caused a crisis of fundamental 
proportions for academic librarians. To extend the military analogy suggested by the earlier discussion of strategy and tactics, the ranks of academic librarians, perceived by many as having "won" the struggle to provide convenient information, now are in danger of being partly, or even mostly, demobilized. In a world where academic librarian job security is threatened, where the pronouncements of administrators and reassurances of faculty cannot be fully trusted, is there any way that academic librarians can reposition themselves for a productive future within the American academy?

Elements for a positive answer to this question may be found in the experience of another enterprise threatened by its own success-the March of Dimes.

\section{A Goal Achieved? Lessons from the March of Dimes Experience}

In the late 1950s, the National Foundation for Infantile Paralysis, now known as the March of Dimes Birth Defects Foundation, faced a problem that has since led to the organization becoming an often-cited, nearly perfect case study for the problems of organizational transformation. ${ }^{48}$ With the development of an effective oral vaccine, the purpose of the organizationthe eradication of childhood polio-had almost been totally achieved within the borders of the United States. As a result, the March of Dimes was left with two options: It could declare victory and disband an efficient, effective organization that had actually achieved its founding purpose, or it could redirect the expertise embodied in its membership to "a broad goal less likely to ever be fully accomplished." The new goal selected was far larger and much less achievable- - "combating all birth defects." 49

In summarizing prior scholarship, in particular that of Peter M. Blau and W. Richard Scott, on the success of the March of Dimes in redefining itself to solve other problems plaguing contemporary society, Mordecai Lee endorsed the view that the reorientation had been successful because the organization:
1. had considerable public acceptance;

2. was perceived as successful in achieving its goal;

3. had a flexible corporate structure with the ability, interest, and power to implement new policies;

4. had an ability to relate, in an ongoing fashion, to its environment. ${ }^{50}$

Analysis of the ability of academic librarians to exemplify these "survival factors" is complicated by the reality that there are those who prize the resources made available in and through the academic library more than the academic librarian. ${ }^{51}$ However, the ability of the academic library community to meet three of the four factors may actually come close to a "given."

The first factor is public acceptance, and academic librarians have been accepted for decades. Their "publics" - the research/teaching faculty, students, and administrators-have a more or less positive record of interactions with academic librarians in a number of contexts. The second factor, recognition as being successful in achieving its goal of providing greater access to information, seems to be accorded to academic librarianship even by those who argue against the continued viability of the physical library building. Those "innovators" arguing for the elimination of a brick-and-mortar library from accreditation criteria must craft their arguments in an environment made possible by the success of academic librarians in fostering the creation and delivery of new sources of electronic information.

With regard to the third factor, a flexible corporate structure, American academic institutions tend to operate with a corporate configuration where boards of trustees can and do make critical decisions. As Jaroslav Pelikan has stressed, a university or college board of trustees can play a particularly effective role in times of crisis. ${ }^{52}$

The fourth factor, the problematic area still needing to be addressed to allow academic librarianship to reinvent itself, involves the profession's ability to maintain 
a positive relationship with its environment, specifically, its parent university or college. Yet, even here, long-term stresses affecting the academic world as a whole may actually facilitate the ability of academic librarians to carve out new roles.

\section{Effectiveness in Relating to the Larger Academic Environment}

In a fascinating report entitled Ahead of the Game: Developing Academic Library Staff for the $21^{\text {st }}$ Century, Alasdair Paterson, university librarian at the United Kingdom's University of Exeter, described how a team of outside evaluators had found his university to be afflicted by "levels of anxiety and confusion you would expect from a traditional organisation thrown into flux, forced into restructuring and facing the unpredictabilities of change." ${ }^{53}$

There is an enormous variation in context represented by thousands of American academic institutions. Nevertheless, most academic librarians who plan appropriately and demonstrate a willingness to both surface and address the tacit knowledge of the librarian held by administrators and faculty ought to be able to devise effective approaches to reorienting the academic library on the level of the individual campus. However, a fundamental requirement of such a transformation will be the abandonment of the antifaculty and retrograde philosophy encapsulated in the ACRL position paper. An equally, or more important, criterion will be the repeated demonstration of flexibility at levels ranging from the individual librarian to the academic library as a whole.

A number of techniques are useful in surfacing the tacit knowledge of librarians, faculty, and administrators to suggest possible avenues for reorienting the academic librarian on a given campus. A critical element in such planning might be to secure the assistance of a "stranger," perhaps a scholar with a background in higher education or the sociology of higher education, who can help a local community of academic librarians to better understand the university or college context within which it must remake itself.

With or without the assistance of a stranger, academic librarians can help avoid unproductive groupthink-or pressures for uniformity and against exploring alternatives-by employing techniques for surfacing a spectrum of tacit knowledge. For example:

- Brainstorming sessions could be conducted where members can play devil's advocate and reframe questions from the perspective of others. "If I were a researcher or teacher, what would I think about access to electronic information on this campus?")

- Large groups of library staff could be sent on observation visits to libraries that might serve as models for change. Through such visits, large groups develop a shared context for discussion. ("Remember when they showed us how they meet the information needs of students and adjunct faculty who almost never come to campus?")

- The campus could be viewed as an evolving series of niche markets. ("Instead of emphasizing what we academic librarians know we can do well, why don't we find out what the campus communities see as their critical problems and help them develop solutions from the perspective of an academic librarian?" $)^{54}$

Although each academic library community is likely to develop its own strategies for transformation, certain short- and long-term approaches might be productive within a variety of contexts. Implementation of these strategies is not recommended without a full consideration of how effective they might be on a given campus.

\section{Short-term Survival: Librarian as Fellow Teacher?}

Alarm bells should sound in the minds of directors and other senior staff who receive inquiries from academic presidents or provosts asking what the librarians are doing now that information is electronic, being supplied by state or local cooperatives, and few, if any, customers seem to be in the library building. In 
the short run, these library managers might want to consider implementing a number of educationally sound tactics to buy time and preserve budgets while longer-term strategies are being developed. Short-term approaches to enhancing the worth of the academic librarian and use of the library building can include the following programs:

- Program: Create or reinvigorate a popular literature collection on the first floor in a highly visible area equipped with chairs, tables, and comfortable sofas. Justification: Thanks to grade inflation and social promotions, teaching faculty increasingly encounter students, even in graduate LIS programs, with little reading ability and even less understanding of what they do read. ${ }^{55}$ Emerging research now indicates that reading is a skill learned "by reading a lot of text that is meaningful and personally rewarding." ${ }^{56}$ In addition, academic libraries had a proud history of browsing rooms, which was allowed to lapse in favor of information-provision functions. ${ }^{57}$

- Program: Take the ACRL publication Information Literacy Competency Standards for Higher Education and develop forcredit, tuition-generating courses for undergraduates. ${ }^{58}$ These might be "service courses" with a common core, but tailored for students in a variety of fields and disciplines. The ACRL Standards Performance Indicators, and Outcomes are more theoretical than might be expected from practitioners, but they can be a useful start for developing a course. Justification: This is an area that tends to be addressed through library-sponsored workshops but is now ripe for actual courses that many departmental faculty are not inclined to teach. If academic librarians do not preempt the field, similar service courses may well be offered for credit by entrepreneurial colleges of education or other campus competitors who have the advantage of being seen as "real" faculty. In academic environments, "real" faculty are either researchers and/or teachers in actual or cyber classrooms. Faculty tutoring of students, as with independent stud- ies, is often not rewarded within the university but, rather, is expected from faculty as a nebulous part of "student advising." In a classroom-centered teaching environment, the work of librarians at reference desks, a responsibility that does not attract tuition revenue, is unlikely to be valued. However, actual information courses, tailored for students in the fields and disciplines, courses that raise tuition revenue and may attract a state subsidy, are quite another thing. They may represent a soon-to-be-lost opportunity for academic librarians to move beyond a merely technical equality and earn recognition as actual colleagues by those whose valuation of teaching is so closely connected with physical or electronic classrooms.

- Program: Negotiate with the university English or popular culture department for librarians to teach for-credit courses on established or emerging reading genres, with book talks and book discussions included in the syllabus. Justification: The library has already added or reinforced the collection (above). If turf wars can be avoided, who better to help students gain maximum benefit than the librarians who selected or coordinated the selection of works and thereby brought the collection into being?

- Program: Begin or reinforce use of the library for presentations by the research and teaching faculty. Serve refreshments. Justification: These forms of "oral publications," in the words of Merton, allow faculty to explore ideas, engage in debates, and, not least in importance, receive recognition from campus colleagues. ${ }^{59}$ By accepting such invitations from academic librarians, teaching/research faculty extend to them an implicit collegiality.

- Program: Locate an information arcade with a cyber café in a very visible part of the academic library. Place a reference desk next to the public access computers. Justification: In a time of actual or potential cutbacks, the academic library must be a visible gathering place on a campus presumably devoted to intellectual activity. 


\section{Long-term Survival: Librarian as Research Colleague?}

As in the short term, long-term prospects for the academic librarians are likely to be enhanced by adopting faculty duties in an environment where the availability of online resources increasingly detaches the provision of electronic information from those who helped make it possible.

- Program: Continue to expand opportunities for librarians to offer appropriate information, popular literature, and other service courses. Justification: In an environment where the provision of information is less connected to the physical library, academic librarians need to intensify their connection with the teaching faculty.

In the more radical of cost-benefit environments, academic librarians may be teaching "information" in ways that are very similar to how other faculty teach business administration.

- Program: Continue or initiate programs to (1) encourage existing librarians to earn a Ph.D. and (2) hire holders of a doctorate and provide them with a master's degree or an apprenticeship library education. Justification: The Ph.D. has been the qualification of a "real" faculty member since William James attacked the requirement in 1903 in "The Ph.D. Octopus." 60 The doctorate is often the irreducible minimum for participation in academic communities of practice. In "Working Effectively with Scholars," Julie Yang and Don Frank noted that:

Expertise, knowledge, and education are respected in academia. Credentials add credibility. The librarian who understands and speaks the "language" of a specific discipline will communicate more effectively with the scholars in the discipline ${ }^{61}$

It is worth repeating that in the academic world credentials do count. In 1999,
American universities awarded 41,140 doctorates. ${ }^{62}$ The most visible people on research university campuses with only master's degrees tend to be librarians, graduate students, student services personnel, and adjunct faculty. Rebecca Kellogg, a former librarian and head of a reference department, writing as an associate dean of the College of Arts and Sciences with the University of Arizona, put the matter quite simply a number of years ago. Viewing librarians from the perspective of the departmental faculty, she asked, "If they are faculty members, why don't they have a Ph.D.?"63

\section{Closing Questions and Context- specific Answers}

In 1992, just before the explosive growth in Web-based courses and degrees, James $R$. Mingle, then executive director of the State Higher Education Executive Officers Association, presented a paper titled "Faculty Work and the Cost/Quality/ Access Collision" to members of Boards of Visitors of Virginia higher education institutions. ${ }^{64}$ Stressing that higher education was dealing with the often-conflicting areas of cost, quality, and access, Mingle asserted that changes in the American context, including new higher education customers, new economic realities, and new expectations, had made it impossible for higher education to continue as before. Of the several solutions to address the "collision" discussed by Mingle, one seems to have been adopted by the supporters of electronic higher education-to "cut our costs, change our definition of quality and our programs and meet the needs of our customers." 65 Unfortunately, the redefinition of quality now under way seems to be in a downward direction.

With electronic access eliminating the historic connection between information and the university library, and with accrediting bodies on the verge of setting new standards that are likely to make the separation official, academic librarians now are being required to answer a question long put to their colleagues in for-profit envi- 
ronments. Corporate librarians, known more often as information specialists or knowledge managers, have learned to build their careers with this question in mind: If your customers know as much as you do, why do they need you?

Academic librarians are far from the only information professionals who have lost-or soon will lose- the protection of legal or other mandates. Hospital librarians throughout the nation have spent much of the past decade weaving their worth into the larger organization after specific requirements for libraries were dropped. ${ }^{66}$ In the area of school library media services, it is now the case, under standards adopted by the State Board of Education, that "every school library in Ohio will have to prove its worth within the educational environment or risk being eliminated." ${ }^{167}$ Those who would disparage the experience of elementary and secondary education environments as inapplicable within a higher education context would do well to note that "the rapid pace of K-12 change" has been favorably compared with the sluggish nature of the academic world by state officials who, in many cases, have sought "the same transformation for the postsecondary education system." 68

It has been the argument of this essay that the revolution in electronic information brought about in large part by the academic library community has contributed to career uncertainty for its originators. However, even in such an unsettled time, academic librarians who (1) identify, understand, and act on the tacit knowledge of campus administrators and the teaching faculty, their past and (possible) future customers; (2) seize what may be a limited opportunity to remake academic librarianship before it is remade by others; and (3) develop niche markets based on the historic and developing strengths of academic librarianship now have the ability to ally themselves closer than ever with the university priorities of research and teaching. In so doing, they are likely to modify academic librarianship in as many ways as there are academic contexts.
This transformation of higher education's libraries and librarians may well be wrenching. As with the faculty in classrooms and labs, academic librarians at the so-called brand-name institutions are better situated to resist the demands of a market economy. They may even serve out their careers in something approximating a traditional library environment. Librarians at other institutions, specifically the "929 private colleges and universities" deemed potentially "troubled" by Moody's Investors Service because of annual incomes of less than $\$ 20$ million, will have a far more difficult time. ${ }^{69}$ At a minimum, the precarious financial situation of their academic parent may create contexts where librarians are forced into adopting the Internet-influenced norms of the teaching faculty, even if such norms may be problematic in light of traditional academic library practices. As electronic competitors emerge, as information and knowledge databases become more comprehensive and are acquired in cost- and time-saving methods through membership in state or other cooperatives, local understandings that the library "has done its job" may spread. This diffusion of understandings, whether the result of tacit knowledge or tacit ignorance, may require saving the library through its transformation into something resembling a campus teaching department. At its most draconian, students will staff reference desks, others with IT expertise will maintain the availability of electronic information and communication, and Ph.D.-holding librarians with a campus-recognized expertise in teaching information analysis will add to the institutional bottom line through income-producing courses. In the more radical of cost-benefit environments, academic librarians may be teaching "information" in ways that are very similar to how other faculty teach business administration.

As Newman reminded long ago, it is possible, albeit less than ideal, to work in a situation where circumstances require the adoption of second best as practical best. This is particularly the case in higher 
education contexts, for-profit and not-forprofit alike, where cost containment and enhanced profitability have become priorities. Under such circumstances, it is now possible, if erroneous, for administrators to view the current version of academic librarians as increasingly irrelevant. If this perception becomes widespread, can incremental deprofessionalization and even- tual elimination be avoided? Moving the academic librarian from reference desks to brick and electronic classrooms, combined with a context-relevant alliance with researchers grounded in shared credentials and interests, may well be the answer to the academic version of the question, If your customers know as much as you do, why do they need you?

\section{Notes}

1. John Seely Brown and Paul Duguid, The Social Life of Information (Boston: Harvard Business School Pr., 2000), 5-6.

2. The short definition is from Bill Crowley, "Building Useful Theory: Tacit Knowledge, Practitioner Reports, and the Culture of LIS Inquiry," Journal of Education for Library and Information Science 40 (fall 1999): 282.

3. Brown and Duguid, The Social Life of Information, 6 .

4. Jacques Barzun, The American University: How It Runs, Where It Is Going, 2d ed. (Chicago: Univ. of Chicago Pr., 1993), 198.

5. Ibid.

6. John Henry Newman, The Idea of a University (Notre Dame, IN: University of Notre Dame Pr., 1982), 8. Reprint of 1873 edition.

7. Crowley, Building Useful Theory: Enhancing the Research Effectiveness of Faculty, Consultants, and Practitioners, forthcoming.

8. This caution, fundamental to modern pragmatism in most variants, is even more strongly developed in Bill Crowley, "The Dilemma of the Librarian in Canadian Higher Education," Canadian Journal of Information and Library Science 22 (Apr. 1997): 15.

9. Michael Polanyi, The Tacit Dimension (Garden City, N.Y.: Doubleday Anchor), 4

10. Crowley, "Building Useful Theory," 283.

11. Quoted in William J. Broad, "Scientist at Work: Philip E. Coyle, III-Words of Caution on Missile Defense," New York Times, 16 Jan. 2001, national edition, sec. "Science Times," D1.

12. Crowley, "Tacit Knowledge and Quality Assurance: Bridging the Theory-Practice Divide," in Knowledge Management for the Information Professional, ed. T. Kanti Srikantaiah and Michael E. D. Koenig (Medford, N.J.: American Society for Information Science/Information Today, 2000): 205-20.

13. Dorothy Leonard and Sylvia Sensiper, "The Role of Tacit Knowledge in Group Innovation," California Management Review 40 (spring 1998): 126.

14. For an example of electronic alternatives, see Robert V. Antonucci and Joseph M. Cronin, "Creating an Online University," Journal of Academic Librarianship 27 (Jan. 2001): $20-23$.

15. Felix T. Chu, "Librarian-Faculty Relations in Collection Development," Journal of Academic Librarianship 23 (Jan. 1997): 17.

16. Simonetta Tabboni, "The Stranger and Modernity: From Equality of Rights to Recognition of Difference," Thesis Eleven 43 (1995): 18.

17. Georg Simmel, "The Stranger," in The Sociology of Georg Simmel, ed. Kurt H. Wolff (Glencoe, Ill.: Free Pr., 1950), 402-8.

18. See Crowley, "Redefining the Status of the Librarian in Higher Education," College \& Research Libraries 57 (Mar. 1996): 113-21; — " "The Dilemma of the Librarian in Canadian Higher Education"; William A. Crowley Jr., "A Draft Research Model of the Research University Library: Exploring the Scholar-Librarian Partnership of Jaroslav Pelikan" in The Idea of the University: A Reexamination (Ph.D. diss., Ohio Univ., 1995).

19. Correspondence from Donna M. Carroll, president, Dominican University, to William Crowley, associate professor, Graduate School of Library and Information Science, Dec.14, 2000.

20. William G. Tierney, "Facts and Constructs: Defining Reality in Higher Education Organizations," Review of Higher Education 11 (fall 1987): 64.

21. Cited in Larry Hardesty, Do We Need Academic Libraries? A Position Paper of the Association of College and Research Libraries (ACRL) (Chicago: Association of College and Research Libraries, revised Jan. 21, 2000) [cited 19 February 2001]. Available online from http://www.ala.org/acrl/ academiclib.html.

22. Ibid., 4, n. 2 . 
23. Hardesty, "'Libraries' Dropped from Accreditation Criteria," College E Research Libraries News 61 (Nov. 2000): 888.

24. George Ritzer, The McDonaldization Thesis (London: Sage, 1998), 151-62.

25. Charles Homer Haskins, The Rise of Universities (New York: Holt, 1923).

26. See, for example, "The Self-Fulfilling Prophecy," chap. XIII in Robert K. Merton, Social Theory and Social Structure, enl. ed. (New York: Free Pr., 1968), 475-90.

27. Although predating the Web environment, a useful discussion of issues involving control of the classroom is found in Robert E. Young, "Faculty Development and the Concept of 'Profession," Academe 73, no. 3 (May-June 1987): 12-14.

28. Antonucci and Cronin, "Creating an Online University."

29. Stuart Crainer and Des Dearlove, Gravy Training: Inside the Business of Business Schools (San Francisco: Jossey-Bass, 1999), particularly chapter 10, "Uncertain Futures."

30. Ritzer, The McDonaldization Thesis, 161.

31. Clark Kerr, The Uses of the University, $4^{\text {th }}$ ed. (Cambridge, Mass.: Harvard University Pr., 1995), 181-82.

32. John Dewey, Logic: The Theory of Inquiry, in The Later Works, 1925-1953, Vol. 12: 1938, ed. Jo Ann Boydston (Carbondale and Edwardsville, Ill.: Southern Illinois Univ. Pr., 1986), 512.

33. Evan Ira Farber, "Turning Students into Readers: Librarians and Teachers Cooperating," paper presented at the Annual Meeting of the $33^{\text {rd }}$ International Reading Association, Toronto, May 1-6, 1988, EDRS, ED 302807

34. Robert K. Merton, "The Unanticipated Consequences of Purposive Social Action," American Sociological Review 1 (1936): 894.

35. Ibid., 903 .

36. Cameron Fincher, "The Idea of the University in the $21^{\text {st }}$ Century: An American Perspective," British Journal of Educational Studies 41 (Mar. 1993): 34.

37. Wade R. Kotter, "Bridging the Great Divide: Improving Relations between Librarians and Classroom Faculty," Journal of Academic Librarianship 25 (July 1999): 295.

38. Ibid., 295-96.

39. Hardesty, Do We Need Academic Libraries? 2.

40. Young, "Faculty Development and the Concept of 'Profession,'"12.

41. Robert Dingwall, "Atrocity Stories' and Professional Relationships," Sociology of Work and Occupations 4 (Nov. 1977): 395.

42. Kotter, "Bridging the Great Divide," 295.

43. Barzun, The American University.

44. See Meg McSherry Breslin and J. Linn Allen, "City Colleges Faculty and Staff Approve Contract, Despite Opposition," Chicago Tribune, 2000 Oct. 21, sec. 1, 5, for a discussion of how new faculty will be required to teach five classes or 15 hours per semester as opposed to a level of four classes or 12 hours a semester for "senior faculty members"; J. Linn Allen, "City Colleges Teachers Fear Their Jobs Could Go Private," Chicago Tribune, 2001 Feb. 15, sec. 1, 1, 28, for a consideration of "privatizing ... business and computer science teaching."

45. Ibid.

46. Chris Argyris, "Tacit Knowledge and Management," in Tacit Knowledge in Professional Practice: Researcher and Practitioner Perspectives, ed. Robert J. Sternberg and Joseph A. Horvath (Mahwah, N.J.: Lawrence Erlbaum, 1999), 126.

47. Ibid.

48. See the extended discussion in Mordecai Lee, "A Jewish 'March of Dimes'? Organization Theory and the Future of Jewish Community Relations Councils," Jewish Political Studies Review 12 (spring 2000): 3-19.

49. Ibid., 4.

50. Ibid., particularly 5-16.

51. See the extended discussion in Crowley, "A Draft Research Model of the Research University Library."

52. Jaroslav Pelikan, The Idea of a University: A Reexamination (New Haven, Conn.: Yale Univ. Pr., 1992), 74-75.

53. Alasdair Paterson, "Ahead of the Game: Developing Academic Library Staff for the $21^{\text {st }}$ Century," in The Future of Libraries in Human Communication: Abstracts and Full-text Documents of Papers and Demos Given at the IATUL [International Association of Technological University Libraries] Conference, Chania, Greece, May 17-21, 1999, vol. 19. EDRS, ED 433833.

54. An excellent description of approaches for surfacing tacit knowledge can be found in Leonard and Sensiper, "The Role of Tacit Knowledge in Group Innovation."

55. Armando Petrucci, "Reading to Read: A Future for Reading," in A History of Reading in the West, ed. Guglielmo Cavallo and Roger Chartier (Amhurst, Mass.: Univ. of Massachusetts Pr., 1999), 353. 
56. Catherine Sheldrick Ross, "'If They Read Nancy Drew, So What?': Series Book Readers Talk Back," Library E Information Science Research 17 (summer 1995): 232; see also J. A. Appleyard, S.J., Becoming a Reader: The Experience of Fiction from Childhood to Adulthood (Cambridge, Mass.: Cambridge Univ. Pr., 1990).

57. See Farber, "Turning Students into Readers"; Virginia Vesper, "The Readers' Advisory in Academic Libraries" [cited 12 March 2001]. Available online from http:/ / www.mtsu.edu/ itconf/ proceed97/vesper.html; Henry M. Wriston, "The College Librarian and the Teaching Staff," Bulletin of the American Library Association 29 (Apr. 1935): 178-79.

58. Association of College and Research Libraries, Information Literacy Competency Standards for Higher Education (Chicago: ACRL, 2000).

59. Piotr Sztomopka, Robert K. Merton: An Intellectual Profile (New York: St. Martin, 1986), 18.

60. William James, "The Ph.D. Octopus," in Memories and Studies (New York: Greenwood, 1968): 320-47. Reprinted from the Harvard Monthly (Mar. 1903).

61. Julie Yang and Don Frank, "Working Effectively with Scholars: A Key to Academic Library Success," Georgia Library Quarterly 36 (summer 1999): 10.

62. Courtney Leatherman, "The Faculty: The Number of New Ph.D.'s Drops for the First Time Since 1985," Chronicle of Higher Education 47, no. 22 (Feb. 9, 2001) [cited 14 March 2001]. Available online for subscribers only from http:/ / chronicle.com/weekly/v47/i22/22a01001.htm.

63. Rebecca Kellogg, "Beliefs and Realities," College E Research Libraries News 47 (Sept. 1986): 493.

64. James R. Mingle, Faculty Work and the Cost/Quality/Access Collision (Denver, Colo.: State Higher Education Executive Officers/Education Commission of the States). Presentation to Members of Boards of Visitors, Virginia Institutions, Sponsored by the State Council of Higher Education for Virginia, Richmond, October 27, 1992, EDRS, ED 356730.

65. Ibid., 6.

66. Prudence W. Dalrymple and Carol S. Scherrer, “Tools for Improvement: A Systematic Analysis and Guide to Accreditation by the JCAHO," Bulletin of the Medical Library Association 86 (Jan. 1998): 10.

67. Roxane E. Oakley, "New Standards for Ohio Schools and School Libraries," State Library of Ohio News 258 (Nov./Dec. 2000): 2.

68. Donald F. Kettl, "Creating High-performance Postsecondary Education." This is a commissioned paper by the National Governors Association Center for Best Practices [cited 24 March 2001]. Available online from http://nga.org/cda/files/HIGHEREDREINVENTINGHIED.pdf.

69. John C. Nelson, "Moody's Investors Service," cited in Martin van der Werf, "More Colleges Are Seeing the Virtues of Merging," Chronicle of Higher Education 47 (Mar. 23, 2001): A27. 